\title{
KEBUTUHAN ASAM LEMAK ESENSIAL PADA IKAN LAUT
}

\begin{abstract}
H. Pangkey ${ }^{1}$
ABSTRACT

Aquaculture has contributed one third of the world is supply of seafood. This contribution is expected to increase in the future. Based on this reason, aquaculture is potential to continually provide food for human needs. One of the key factors to the success of aquaculture is the supply of nutritious feed. Feeding with food of right nutrition value will produce healthy and high quality fish. One of the nutrient elements that plays an important role in aquatic organism growth is lipid. Lipids in the form of essential fatty acids are highly required not only for broodstock and larvae, but also for normal growth of marine fish.
\end{abstract}

Keywords : aquaculture, lipid, essential fatty acid.

\begin{abstract}
ABSTRAK
Akuakultur telah memberikan kontribusi sebesar sepertiga kebutuhan dunia akan produk makanan laut, dan akan terus bertambah di masa depan. Dipandang dari sudut ini, akuakultur memiliki prospek untuk menjadi usaha berkelanjutan dalam menyediakan pangan bagi populasi manusia yang terus bertambah. Salah satu faktor yang menentukan keberhasilan dalam usaha akuakultur adalah penyediaan pakan dengan kandungan nutrisi yang optimal. Pemberian pakan dengan komponen nutrisi yang tepat dapat menghasilkan ikan yang sehat dan berkualitas tinggi. Salah satu komponen nutrisi yang sangat berperan dalam pertumbuhan biota akuakultur adalah lipida. Lipida berupa asam lemak esensial sangat dibutuhkan baik oleh induk dan larva, juga untuk pertumbuhan secara normal ikan laut.
\end{abstract}

Kata kunci : budidaya ikan, lipid, essential fatty acid.

${ }^{1}$ Staf pengajar Fakultas Perikanan dan IImu Kelautan Universitas Sam Ratulangi, Manado, Sulawesi Utara

\section{PENDAHULUAN}

Tidak diragukan lagi bahwa usaha penangkapan ikan di alam sedang berada dalam keadaan krisis. Keadaan ini telah dibuktikan melalui riset mendalam terhadap hasil penangkapan ikan global (Pauly et al., 2002; Meyers \& Worm, 2003). Di lain pihak, kontribusi akukultur terhadap total produksi perikanan dunia meningkat secara signifykan, dan saat ini sekitar $30 \%$ kebutuhan dunia akan bahan makanan laut dipenuhi oleh akuakultur. Peran ini diprediksi terus meningkat dimasa depan, dimana akuakultur akan secara berkelanjutan menyediakan pangan bagi populasi manusia yang terus bertambah secara eksponensial.

Keberhasilan usaha akuakultur sangat ditentukan oleh penyediaan pakan dengan kandungan nutrisi yang cukup. Biaya untuk penyediaan pakan mengambil porsi sekitar $40-50 \%$ dari total biaya operasional akuakultur (Craig \& Helfrich, 2002). Pakan harus mengandung semua komponen nutrisi penting agar ikan memiliki kemampuan untuk bertahan terhadap penyakit dan tumbuh sesuai yang diinginkan. Pemberian pakan dengan komponen nutrisi yang tepat dapat menghasilkan produk ikan yang sehat dan berkualitas tinggi. Beberapa komponen nutrisi yang penting bagi pertumbuhan ikan adalah protein, lemak, karbohidrat dan vitamin. Setiap komponen mempunyai peranannya masing-masing dalam pakan. Artikel ini membahas kebutuhan lemak bagi ikan laut.

\section{Lipida}

Lipida adalah kelompok lemak yang terdapat dalam jaringan tanaman maupun hewan. Lipida diklasifikasikan sebagai: lemak, fosfolipida, sfingomielin, lilin dan sterol (Fahy et al., 2005). Semua lipida ini memiliki kesamaan serta kekhususannya 
yang ditentukan oleh jumlah hidrokarbon dalam molekulnya. Lemak adalah ester asam lemak dari gliserol dan tersimpan sebagai energi dalam tubuh hewan. Lemak digunakan untuk kebutuhan energi jangka panjang, juga untuk pergerakan atau cadangan energi selama periode kekurangan makanan. Dalam tubuh, lemak menyediakan energi dua kali lebih besar dibandingkan protein (Sargent et al., 2002); Fosfolipida adalah gabungan ester asam lemak dan asam fosfatidat, merupakan komponen utama dari membran sel, dan membantu permukaan membran untuk bersifat hidrofobik ataupun hidrofilik. Spingomielin adalah ester asam lemak dari sfingosin dan terdapat dalam otak dan jaringan saraf. Lilin adalah ester asam lemak dan alkohol rantai panjang dan dapat dijumpai pada jaringan telur, hati dan otot. Sterol adalah rantai panjang alkohol yang tersusun secara polisiklik dan berfungsi sebagai komponen dari beberapa hormon untuk kematangan gonad.

Lemak dalam makanan umumnya berada dalam bentuk trigliserida dan diuraikan dalam tubuh menjadi asam lemak yang bebas. Fraksi lemak ini dapat diklasifikasikan sebagai lilin dalam bentuk ester, sterol, steril ester, triasilgliserida, diasilgliserida, diasilgliseril ester, monogliserida, fosfolipida dan asam lemak bebas.

\section{Lipida pada ikan laut}

Bagi ikan laut, lemak merupakan sumber nutrisi utama (Froyland et al.,2000; Sargent et al., 2002; Tocher, 2003). Jaringan lemak yang berwarna putih dalam tubuh bertanggung jawab terhadap sintesa lipida, penguraian dan penyimpanan lemak dalam tubuh organisme (Szkudelski et al., 2009). Lokasi penyimpanan lemak utama dalam tubuh ikan adalah otot dan hati, ada juga yang tersimpan sebagai lemak mesentrik (Sheridan, 1988).

Kandungan lemak dalam otot ikan sangat bervariasi (Tabel 1). Hal ini sangat bergantung pada spesis, umur, pemijahan, pakan dan tipe otot (Gehring et al., 2009). Riset mengenai struktur daging ikan telah dilakukan oleh banyak ahli dan ikan hidup biasanya mengandung lemak 2 - $12 \%$ (Alasalvar et al., 2002; Grigorakis et al.,
2002; Jankowska et al., 2003; Orban et al., 2003; Kamal et al., 2007).

Tabel 1 : Komposisi kimia beberapa ikan air tawar dan ikan air laut

\begin{tabular}{|c|c|c|c|}
\hline Spesis & Nama ilmiah & Air $\%$ & $\begin{array}{c}\text { Lemak } \\
\%\end{array}$ \\
\hline Bass & Morone labrax & 77 & 2,5 \\
\hline Carp & Cyprinus carpio & $78-80$ & $2,0.2,2$ \\
\hline Catfish & Anarhichas sp. & 78 & $2,1-3,8$ \\
\hline Cod & Gadus morhua & $78 \cdot 83$ & $0,1=0,9$ \\
\hline Dogfish & Squalus acenthias & 75 & $3,9 \cdot 5,6$ \\
\hline Eel & Anguilla anguille & 60.71 & $8,0-31,0$ \\
\hline Flounder & Platichthys fiesus & 81 & 0,3 \\
\hline grey mullet & Mugil sp. & 76 & 3,9 \\
\hline Halibut & Hippoglossus hippoglossus & $75-79$ & $0,5 \cdot 9,6$ \\
\hline Herring & Clupea harengus & 60.80 & $0,4-22,0$ \\
\hline Mackerel & Scomber scombrus & 60.74 & $1,0-23,5$ \\
\hline Perch & Perca fluvietilis & $79 \cdot 80$ & 0,8 \\
\hline Plaice & Pleuronectes platessa & 81 & $1,1-3,6$ \\
\hline Pollack & Gadus pollachius & 79 & $0,6-0,8$ \\
\hline Salmon & Salmo saler & $67-77$ & $0,3-14,0$ \\
\hline sea bream & Sparus centrodontus & 79 & 1,5 \\
\hline Skate & Raja sp. & $77-82$ & $0,1-1,6$ \\
\hline Sole & Solea solea & 78 & 1,8 \\
\hline Trout & Salmo trutta & 70.79 & $1,2-10,8$ \\
\hline Tuna & Thunnus sp. & 71 & 4-1 \\
\hline
\end{tabular}

Sumber : Murray and Burt, 2001

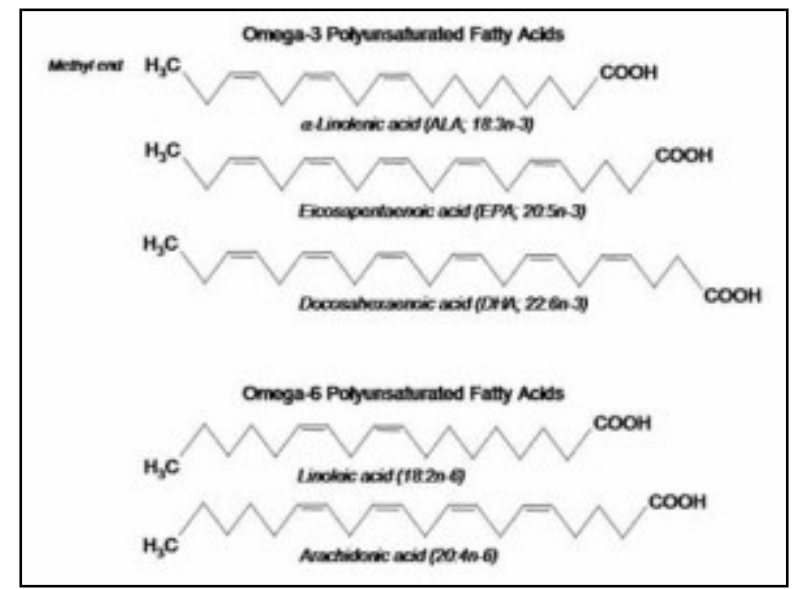

Gambar 1. Asam lemak tidak jenuh yang dibutuhkan ikan (Rustan and Drevon, 2005)

Asam lemak yang dihasilkan dalam tubuh, akan dibentuk lagi menjadi (1) trigliserida netral, yang kelak dapat digunakan sebagai energi; (2) fosfolipida dan glikolipida yang bersifat polar untuk pembentukkan membran sel (Bhouri et al., 2010) ; (3) sterol yang bersifat non polar, dimana sangat penting untuk sel saraf juga dalam membran sel; (4) asam lemak bebas yang nantinya akan membentuk asam lemak yang lebih kompleks melalui bantuan enzim; (5) lemak yang dapat melarutkan vitamin, karotenoid, dan sebagainya. 


\section{Asam lemak esensial pada ikan laut}

Selain hal-hal yang telah disebutkan di atas, lipida juga berperan utama sebagai sumber asam lemak esensial, yang sangat berperan dalam pertumbuhan yang normal, perkembangan dan reproduksi ikan (Sargent et al., 2002; Leaver et al., 2008).

Asam lemak esensial adalah komponen lipida yang sangat penting nilai nutrisinya yang tidak dapat dibentuk dalam jumlah yang cukup oleh hewan dan harus diperoleh dari makanan. Kebutuhan asam lemak esensial untuk ikan laut dipengaruhi oleh suhu dan salinitas perairan (Cowey \& Sargent, 1979).

Ikan air tawar tidak membutuhkan asam lemak tidak jenuh (HUFA) rantai panjang, tetapi asam lemak jenis C18 n-3 yaitu asam linolenat (18:3-n-3) dengan konsentrasi berkisar antara 0,5 - 1,5\% dalam pakan (Craig \& Helfrich, 2002). Asam lemak ini tidak dapat diproduksi dalam tubuh dan harus diperoleh dari pakan, kemudian dengan bantuan enzim diubah menjadi rantai hidrokarbon yang panjang. Pembentukan ikatan ganda membentuk HUFA, EPA dan DHA sangat penting untuk fungsi metabolik dan komponen dalam membran sel (Craig \& Helfrich, 2002; Lall et al., 2002). Ikan laut tidak memiliki sistim enzim seperti yang ada pada ikan air tawar, sehingga ikan laut sangat membutuhkan HUFA rantai panjang n-3 dan n-6 dari pakan untuk pertumbuhan yang optimum (Ibeas et al., 2000; Yildiz, 2008). Asam lemak esensial yang sangat dibutuhkan ini adalah asam eikosapentanoat (EPA) $(20: 4 n-6)$ dan asam dokosaheksaenoat (DHA) (22:6n-3) juga asam arakidonat (AA) $(20: 4 n-6)$ (Higgs \& Dong, 2000; Seiffert et al., 2001; Tocher, 2003) (Gambar 1). Biasanya asam lemak tidak jenuh ini disintesis dari asam lemak C-18. EPA dan DHA dibutuhkan untuk fungsi membran sel, sedangkan DHA sangat penting untuk membran sel dari jaringan saraf dan sebagai prekursor untuk pembentukan eikosanoat yaitu beberapa macam hormon (Tocher, 2003). Fungsi AA adalah sebagai prekursor asam lemak eikosanoat (prostaglandin, thromboxane dan leuktriene) pada ikan (Sargent et al., 1999) dan merupakan salah satu komponen utama fosfatidillinositol (PI).
Kekurangan asam lemak esensial
akan menyebabkan gangguan pada kesehatan ikan termasuk di dalamnya berkurangnya fekunditas dan kemampuan membentuk embrio, kematian larva dan pertumbuhan abnormal, pigmentasi yang salah, penglihatan yang cacat, ketidakmampuan untuk makan pada intensitas cahaya yang rendah, tingkah laku yang abnormal dan menurunnya fungsi membran pada suhu yang rendah (Tocher, 2003). Kebutuhan asam lemak esensial bagi spesis ikan laut berkisar antara 0,5-2\% dari berat pakan kering (NRC, 1993). Kebutuhan ini juga sangat tergantung pada kemampuan ikan secara alami dalam menguraikan asam lemak esensial baik secara anabolis maupun katabolis (Sargent et al., 2002). Sumber utama asam lemak esensial n-3 untuk pakan ikan adalah tepung ikan (Miles \& Chapman, 2006; Tacon \& Metian, 2008) dan minyak ikan laut serta sumber-sumber lain yang dapat digunakan sebagai subsitusi dari bahan sebelumnya (Aas et al., 2006; Anonimous, 2008; Olsen et al., 2006; Atalah et al., 2007; Olsen et al., 2007). Kandungan lemak dalam ransum pakan ikan biasanya $15 \%$, dimana ini sangat berkorelasi dengan kandungan asam lemak esensial (Litzsow et al., 2006).

\section{Kebutuhan asam lemak esensial bagi larva ikan laut}

Produksi larva yang masih berukuran sangat kecil dengan masa pertumbuhan yang cepat serta stadia hidup yang masih rentan merupakan masalah dalam akuakultur secara komersil pada kebanyakan spesis ikan laut. Isu utama dalam pengembangan akuakultur berkelanjutan adalah menghasilkan telurtelur yang berkualitas baik dan penyediaan pakan larvanya (Sargent et al., 2002; Brown et al., 2003).

Pada pemeliharaan larva setelah masa penyerapan kuning telur selesai, pemberian pakan hidup dengan nutrisi yang tepat sangat perlu bagi pertumbuhan larva. Larva membutuhkan HUFA rantai panjang $(C \geq 20$ dengan ikatan ganda $\geq 3$ ) (Izquierdo et al., 2000). Kebutuhan HUFA untuk ukuran juvenil berkisar antara 0,5 $1,0 \%$ berat kering pakan; namun kebutuhan pada larva stadia awal lebih 
tinggi lagi yaitu > 4\% (Leger et al, 1986). Larva membutuhkannya karena pertumbuhan yang cepat serta untuk pembentukkan awal dari sel dan jaringan. Hal ini dapat dipenuhi melalui produk pakan alami yang dikayakan secara komersial (Veloza et al., 2006). Plankton mengandung beberapa asam lemak esensial yang tinggi dan baik bagi pertumbuhan (Hirche et al., 2003; Bell et al., 2007; Caramujo et al., 2008). Asam lemak esensial yang terpenting adalah docosahexaenoic acid (DHA; 22:6n-3) dan eicosapentaenoic acid (EPA; 20:5n-3), yang berperan untuk kelangsungan hidup larva serta pertumbuhan yang normal (Watanabe, 2007). Asam lemak esensial ini merupakan komponen utama dari fosfolipida pada membran serta pada jaringan saraf. Larva saat pertama kali makan memiliki indeks neurosomatik yang sangat tinggi sehingga membutuhkan ( $n-3$ HUFA) yang tinggi pula, supaya tidak mengalami kelainan pada pembentukkan saraf. Selain kedua jenis asam lemak di atas, arachidonic acid (20:4n-6; AA) juga sangat dibutuhkan oleh larva. Kedua jenis asam lemak yaitu AA dan EPA adalah substrat yang dibutuhkan untuk pembentukan eikosanoat yang berperan dalam berbagai fungsi fisiologi diantaranya pengaturan ion dan kematangan telur pada induk betina (Copeman et al., 2002). Untuk pertumbuhan larva yang optimum, komposisi dari ketiga jenis asam lemak esensial yang penting ini (DHA, EPA dan AA) harus berada pada kisaran yang tepat. Dalam produksi larva secara komersil, brine shrimp (Artemia salina) dan rotifer (Brachionus plicatilis) sangat lazim digunakan (Copeman et al., 2002). Di samping kedua jenis pakan alami tersebut di atas, kopepoda juga baik bagi nutrisi larva (Han et al., 2000; Stottrup, 2000; Cutts, 2003). Proses pengkayaan (penambahan n-3 HUFA) pada pakan alami memberikan efek yang sangat positif pada pertumbuhan dan kelangsungan hidup larva (Hafezieh et al., 2009). Nilai lipida (EPA) dari rotifer, artemia dan kopepod setelah dikayakan masing-masing adalah $\pm 9,7 \%$ (Park et al., 2006); $\pm 20,9 \%$ (Hafezieh et al., 2008) dan $\pm 24 \%$ (Evjemo et al., 2003).
Faktor lingkungan seperti suhu, salinitas dan cahaya mempengaruhi komposisi lipida pada jaringan tubuh larva, dengan demikian kebutuhan asam lemak esensial juga sangat dipengaruhi oleh kondisi lingkungan yang ada (Penha-Lopez et al., 2005). Semakin tinggi derajat ketidak-jenuhan asam lemak tersebut, maka semakin tinggi tingkat pencairannya, dan ini sangat berhubungan dengan suhu lokasi budidaya. Sebagai contoh, penurunan suhu air sangat berhubungan dengan bertambahnya kandungan PUFA dalam jaringan ikan mas, juga kandungan DHA pada ikan salmon (Izquierdo, 2005 \& Miller, 2007). Juga telah dipelajari, bahwa dengan menurunnya suhu sangat mempengaruhi kerja enzim untuk metabolisme lipida (lipolysis dan lipogenesis), juga meningkatnya kapasitas oksidasi ikan rainbow trout (Tocher, 2003). Meningkatnya kandungan PUFA, khususnya DHA (docosahexaenoic) dan AA (arachidonic acid) juga ditemukan pada ikan guppy (Poecilia reticulata) dan bandeng (Chanos chanos) saat salinitas meningkat, menunjukkan pentingnya peran asam lemak tersebut di atas terhadap pengaturan osmoregulasi serta ketahanan terhadap stres (Lall, 2000; Balfry \& Higgs, 2001; Place \& Harel, 2006).

Larva ikan saat makan sangat membutuhkan visual yang optimal. Dengan demikian perkembangan penglihatan pada ikan-ikan sangat penting. Seperti halnya pada gilthead seabream dan red porgy (Roo et al., 1999), perkembangan struktur penglihatan terjadi pada stadia embrio; alat penerima cahaya sangat penting untuk melihat dengan tepat meskipun pada intensitas cahaya yang rendah (pada gilthead seabream organ mata terbentuk 18 hari setelah menetas). Asam lemak esensial terutama DHA berperan sangat penting dalam pembentukkan jaringan retina dan saraf. Studi menunjukkan kandungan DHA dan EPA yang tinggi pada gilthead seabream dapat meningkatkan diameter bola mata gilthead seabream, meningkatnya jumlah fotoreseptor, sehingga memperbaiki ketepatan penglihatan (Izquierdo et al., 2000). 


\section{Kebutuhan asam lemak esensial bagi induk ikan laut}

Asam lemak tidak hanya berperan untuk larva ikan, tetapi juga sangat penting bagi reproduksi (Izquierdo, 2005). Menurunnya populasi ikan cod di perairan New Foundland diakibatkan oleh tidak adanya ketersediaan minyak ikan capelin (Mallotus villosus) yang kaya akan asam lemak esensial n-3 sebagai sumber nutrisi penunjang reproduksi ikan cod (Rose, 2001). Reproduksi yang berhasil sangat ditentukan oleh adanya lemak yang dibutuhkan oleh induk juga untuk perkembangan embrio. Pemahaman akan interaksi antara nutrisi dan reproduksi serta pengetahuan akan kebutuhan nutrisi guna berhasilnya kematangan gonad dan pemijahan merupakan jawaban bagi keberhasilan produksi pada panti pembenihan dengan volume yang besar. Nutrisi mempunyai dampak yang nyata terhadap perkembangan ovari, jumlah telur dan perkembangan larva (Mazorra et al.2003), namun nutrisi untuk induk masih memerlukan studi yang mendalam (Izquierdo et al., 2001).

Saat pemijahan, nutrien diambil dari cadangan makanan yang ada dalam tubuh ikan. Ransum pakan induk serta lamanya pemberian pakan penting dipelajari, karena berhubungan dengan lamanya perkembangan telur sebelum pemijahan. Selama pemijahan diketahui bahwa kemampuan makan induk berkurang terutama induk betina, menyebabkan terjadinya penurunan berat $(10-50 \%)$ (Lambert \& Dutil, 2000). Penurunan berat badan diperkirakan berhubungan dengan keadaan tubuh dan perubahan hormon (Thorsen et al., 2003), sehingga kandungan nutrisi dalam pakan sangat penting bagi induk.

Dalam menyusun formula untuk pakan induk, lipida merupakan komponen yang sangat menentukan bagi fungsi reproduksi dari induk betina, demikian pula perkembangan embrio serta kelangsungan hidup pada saat masa penyerapan kuning telur (Mazorra et al., 2003). Kebutuhan ini sangat berbeda dengan kebutuhan pada larva dan juvenil (Ishizaki et al., 2001; Izquierdo et al., 2001; Dabrowski \& Ciereszko, 2001;). Informasi lain yang dapat digunakan dalam menyusun formula pakan bagi induk adalah siklus hidup, kebiasaan makan dan habitat ikan tersebut (Dalsgaard et al., 2003; Bransden et al., 2007) demikian pula komposisi asam lemak telur ikan (Rosa et al., 2007) dapat menjadi petunjuk untuk menyusun ransum pakan induk ikan.

Lipida yang dimaksud di atas terutama golongan PUFA seperti eicosapentaenoic acid (20:5 n-3; EPA) dan docosahexaenoic acid (22:6 n-3; DHA) telah terbukti berhubungan erat dengan keberhasilan reproduksi ikan (Watanabe \& Vassallo-Agius, 2003; Li et al., 2005). Beberapa studi menunjukkan kebutuhan lipida justru tertinggi saat vitellogenesis (pembentukan kuning telur). Kebutuhan akan EPA dimulai pada periode previtellogenesis sampai kepada proses ovulasi. Dengan demikian EPA dan DHA penting sekali ditambahkan sebagai zat tambahan dalam pakan induk untuk pertumbuhan dan perkembangan larva yang normal. Penambahan asam lemak esensial dalam pakan induk dapat dilakukan melalui pemberian pakan hidup yang telah dikayakan ataupun pakan komersial yang sudah ditentukan formulanya (Sargent et al. 2002; Lane \& Kohler, 2006). Kombinasi yang tepat antara DHA dan AA ditemukan juga dapat mempercepat tingkat pemijahan serta laju penetasan; juga meningkatkan ketahanan hidup larva (Furuita et al., 2003; Place \& Harel, 2006; Sawanboonchun, 2009).

\section{KESIMPULAN}

Kesimpulan yang dapat ditarik dari penelitian ini adalah: lipida terutama asam lemak esensial memiliki peranan yang penting dalam tubuh ikan terlebih khusus pada masa matang gonad dan kelangsungan hidup larva. Ikan laut tidak memiliki sistim enzim seperti yang ada pada ikan air tawar, sehingga ikan laut sangat membutuhkan HUFA rantai panjang n-3 dan n-6 dari pakan untuk pertumbuhan yang optimum. Oleh karenanya dalam usaha akuakultur ikan laut yang berkelanjutan, diperlukan penyusunan ransum dengan kandungan nutrisi yang baikuntuk pakan induk dan larva. 
Selanjutnya, dapat direkomen-
dasikan sebagai berikut: komponen nutrisi yang penting untuk diramu dalam pakan selain lipida yaitu protein serta beberapa vitamin yang penting seperti vitamin C dan E. Untuk ini perlu studi lebih lanjut mengenai kombinasi yang tepat dari komponen-komponen nutrisi ini, sehingga memberi fungsi yang seimbang bagi peruntukannya.

\section{DAFTAR PUSTAKA}

Aas, T. S., Hatlen, B., Grisdale-Helland, B., Terjesen, B. F., Bakke-McKellep, A. M. \& Helland, S. J., 2006. Effects of diets containing a bacterial protein meal on growth and feed utilisation in rainbow trout (Oncorhynchus mykiss). Aquaculture, 261, $357-368$.

Alasalvar, C., Taylor, K.D.A., Zubcov, E., Shahidi, F., \& Alexis, M., 2002. Differentiation of cultured and wild sea bass (Dicentrarchus labrax): total lipid content, fatty acid and trace mineral composition. Food Chem., 79, 145 - 150

Anonimous, $2008 . \quad$ Insect-derived replacement a step nearer. Fish Farming International, 35, 23 p.

Atalah, E., Cruz, C. M. H., Izquierdo, M. S., Rosenlund, G., Caballero, M. J., Valencia, A. \& Robaina, L., 2007. Two micro algae Crypthecodinium cohnii and Phaeodactylum tricornutum as alternative source of essential fatty acids in starter feeds for sea bream (Sparus aurata). Aquaculture, 270, 178 - 185.

Balfry, S.K. \& Higgs, D.A., 2001. Influence of dietary lipid composition on the immune system and disease resistance of finfish. In: Nutrition and Fish Health (eds. C. Lim and C.D. Webster), The Haworth Press Inc., New York, 213 234.

Bang, H.O., Dyerberg, J., \& Nielsen, A.B., 1971. Plasma lipid and lipoprotein pattern in Greenlandic west-coast Eskimos. The Lancet, 297, No. 7710, 143 - 1146.

Bell, M.V., Dick, J.R., Anderson, T.R. \& Pond, D.W., 2007. Application of liposome and stable isotope tracer techniques to study polyunsaturated fatty acid biosynthesis in marine zooplankton. Journal of Plankton Research, 29, 417 422.

Bhouri, A.M., Bouhle, I., Chouba, L., Hammami M., El-Cafsi, M. \& Chaouch A., 2010. Total lipid content, fatty acid and mineral compositions of muscles and liver in wild and farmed sea bass (Dicentrarchus labrax). Afr. J. Food. Sci., 4, $522-530$.

Bouriga, N., Selmi, S., Faure, E. \& Trabelsi, M., 2010. Biochemical composition of three Tunisian silverside (fish) populations caught in open sea, lagoon and island coasts. Afr. J. Biotechnol., 9, 4114 - 4119.

Bransden, M.P., Battaglene, S.C., Goldsmid, R.M., Dunstan, G.A., Nichols P.D., 2007. Broodstock condition, egg morphology and lipid content and composition during the spawning season of captive striped trumpeter, Latris lineate. Aquaculture, 268, Issues 1-4, 2 -12 .

Brown, J.A., Minkoff, G. \& Puvanendran, V., 2003. Larviculture of Atlantic cod (Gadus morhua): progress, protocols and problems. Aquaculture, 227, 357 372.

Caramujo, M.J., Boschker, H.T.S., \& Admiraal, W., 2008. Fatty acid profiles of algae mark the development and composition of harpacticoid copepods. Freshwater Biology, 53, 77 - 90.

Copeman, L.A., Parrish, C.C., Brown, J.A. \& Harel M.., 2002. Effects of docosahexaenoic, eicosapentaenoic, and arachidonic acids on the early growth, survival, lipid composition and pigmentation of yellowtail flounder (Limanda ferruginea): a live food enrichment experiment. Aquaculture, $210,285-304$.

Cowey, C.B. \& Sargent, J.R., 1979. Nutrition. In: Hoar, W.S., Randall, D.J., Brett, J.R. (Eds.), Fish Physiology, Vol. VIII. Academic Press, Orlando, FL, 1 69.

Cutts, C.J., 2003. Culture of harpacticoid copepods: potential as live feed for 
rearing marine fish. Advances in Marine Biology, 44, 295 - 317.

Craig, S. \& Helfrich, L.A., 2002. Understanding Fish Nutrition, Feeds, and Feeding. Virginia Polytechnic Institute and State University. $18 \mathrm{p}$.

Dabrowski, K. \& Ciereszko, A., 2001. Ascorbic acid and reproduction in fish: endocrine regulation and gamete quality. Aquaculture Research, 32, 8, 623 - 638.

Evjemo, J.O., Reitan, K.I. \& Olsen, Y., 2003. Copepods as live food organisms in the larval rearing of halibut larvae (Hippoglossus hippoglossus L.) with special emphasis on the nutritional value. Aquaculture, 227, 191 - 210.

Fahy, E., Subramaniam, S., Brown, H., Glass, C.K., Alfred, H., Merrill, Jr., Murphy, R.C., Raetz, C.R.H., Russell, D.W., Seyama, Y., Shaw, W., Shimizu, T., Spener, F., Gerrit, van Meer, VanNieuwenhze, M.S., White, S.H., Witztum, J.L., and Dennis, E.A., 2005. A comprehensive classification system for lipids. Journal of Lipid Research, 46, 839 $-861$.

Froyland, L., Lie, O. \& Berge, R.K., 2000. Mitochondrial and peroxisomal betaoxidation capacities in various tissues from Atlantic salmon, Salmo salar. Aquaculture Nutrition, 6, $85-89$.

Furuita, H., Yamamoto, T., Shima, T., Suzuki, N., \& Takeuchi, T., 2003. Effect of arachidonic acid levels in broodstock diet on larval and egg quality of Japanese flounder Paralichthys olivaceus. Aquaculture, 220, 725 - 735.

Gehring, C.K., Davenport, P.M. \& Jaczynzki, J., 2009. Functional and nutritional quality of protein and lipid recovered from fish processing byproducts and underutilized aquatic species using isoelectric solubilization/precipitation. Curr. Nutr. Food Sci., 5, 17 - 39.

Grigorakis, K., Alexis, M.N., Taylor, K.D.A., \& Hole, M., 2002. Comparison of wild andcultured gilthead sea bream (Sparus aurata); composition, appearance and seasonal variations. Int. J. Food Sci. Technol. 37, $477-484$
Hafezieh, M., Kamarudin, M.S. \& Agh, N., 2008. Nutritional Enhancement of Total Lipid, n-3 and n-6 Fatty Acids in Artemia urmiana Nauplii by Enriching with ICES/30/4. Pakistan Journal of Biological Sciences, 11, $2167-2170$.

Hafezieh, M., Kamarudin, M.S., Saad, C.R.B., Sattar, M.K.A., Agh, N., and Hosseinpour, H., 2009. Effect of Enriched Artemia urmiana on Growth, Survival and Composition of Larval Persian Sturgeon. Turkish Journal of Fisheries and Aquatic Sciences, Vol. 9, $201-207$.

Han, K.M., Geurden, I., and Sorgeloos, P., 2000. Enrichment strategies for Artemia using emulsions providing different levels of $n-3$ highly unsaturated fatty acids. Aquaculture, 183, $335-347$.

Higgs, D.A. and Dong, F. M., 2000. Lipids and fatty acids. In: Encyclopedia of Aquaculture (ed. R.R. Stickney), John Wiley and Sons, Inc., New York, 476 496.

Hirche, H.J., Fetzer, I., Graeve, M. and Kattner, G., 2003. Limnocalanus macrurus in the Kara Sea (Arctic ocean): an opportunistic copepod as evident from distribution and lipid patterns. Polar Biology, 26, 720 - 726.

Ibeas, C., Rodriguez, C., Badia, P., Cejas, J.R., Santamaria, F.J., Lorenzo, A., 2000. Efficacy of dietary methyl esters of n-3 HUFA vs. triacylglycerols of $n-3$ HUFA by gilthead seabream (Sparus aurata L.) juveniles. Aquaculture, 190, $273-287$.

Ishizaki, Y., Masuda, R., Uematsu, K., Shimizu, K., Arimoto, M., and Takeuchi, T. 2001, The effect of dietary docosahexaenoic acid on schooling behaviour and brain development in larval yellowtail. Journal of Fish Biology, 58, 6, 1691 - 1703.

Izquierdo, M.S., Socorro, J., Arantzamendi, L. and Hernandez-Cruz, C.M., 2000. Recent advances in lipid nutrition in fish larvae. Fish Physiol. Biochem., 22, 97 107.

Izquierdo, M. S., Fernandez-Palacios, H., and Tacon, A. G. J., 2001. Effect of 
broodstock on reproductive performance in fish. Aquaculture, 197, 25 - 42.

Izquierdo, M., 2005. Essential fatty acid requirements in Mediterranean fish species. Cahiers Options Mediterraneennes, 63, 91 - 102.

Jankowska, B., Zakęes, Z., Zmijewski, T., and Szczepkowski, M. 2003. A comparison of selected quality features of the tissue and slaughter yield of wild and cultivated pikeperch Sander lucioperca (L.). Eur. Food. Res. Technol. 217: 401-405.

Kamal, D., Khan, N.A., Rahman, M.A and Ahamed, F., 2007. Biochemical Composition of Some Small Indigenous Freshwater Fishes from the River Mouri, Khulna, Banglagesh. Pak. J. Biol. Sci., 10,9, 1559 - 1561.

Lall, S.P., 2000. Nutrition and health of fish. In: Cruz -Suarez, L.E., Ricque-Marie, D., Tapia-Salazar, M., Olvera-Novoa, M.A. Civera-Cerecedo, R., (Eds.). Avances en Nutricion Acuicola V. Memorias del V Simposium Internacional de Nutricion Acuicola. 19-22 Noviembre, 2000. Merida, Yucatan, Mexico, 13 - 23

Lall, S.P., Milley, J.E., Higgs, D.A., and Balfry, S.K., 2002. Dietary lipids, immune function and pathogenesis of disease in fish. http://www-heb.pac.dfompo.gc.ca/congress/2002

/Biochem/Lall.pdf. diambil tanggal 18 Oktober 2011, Jam 11.10 wita

Lambert, Y. and Dutil, J. D., 2000. Energetic consequences of reproduction in Atlantic cod (Gadus morhua) in relation to spawning level of somatic energy reserves. Canadian Journal of Fisheries and Aquatic Sciences, 57, 4, $815-825$.

Lane, R.L. and Kohler, C.C., 2006. Comparative Fatty Acid Composition of Eggs from White Bass Fed Live Food or Commercial Feed. North American Journal of Aquaculture, 69, 11 - 15.

Leaver, M.J., Bautista, J.N., Bjornsson, B.T., Jonsson, E., Krey, G., Tocher, D.R., and Torstensen, B.E., 2008. Towards fish lipid nutrigenomics: Current state and prospects for fin-fish aquaculture. Rev. Fish. Sci., 16, 73 94.

Leger, P., Bengston, D.A., Simpson, K.L. and Sorgeloos, P., 1986. The use and nutritional value of artemia as a food source. Oceanog. Mar. Biol.. Ann. Rev., $24,521-624$.

Li, Y.Y., Chen, W.Z., Sun, Z.W., Chen, J.H. and Wu, K.G., 2005. Effects of $n-3$ HUFA content in broodstock diet on spawning performance and fatty acid composition of eggs and larvae in Plectorhynchus cinctus. Aquaculture,

$245,263-272$.

Litzow, M.A., Bailey, K.M., Fredrick, G. and Prahl, H.R., 2006. Climate regime shifts and reorganization of fish communities: the essential fatty acid limitation hypothesis. Mar. Ecol. Prog. Ser., 315, 1 $-11$.

Mazorra, C., Bruce M., Bell J. G., Davie A., Alorend E., Jordan, N., Rees J., Papanikos N., Porter M. and Bromage N., 2003. Dietary lipid enhancement of broodstock reproductive performance and egg and larval quality in Atlantic halibut (Hippoglossus hippoglossus). Aquaculture, 227, $21-33$.

Meyers, R.A. and Worm, B., 2003. Rapid worldwide depletion of predatory fish communities. Nature, 423, 280 - 283.

Miller, M.R., 2007. The assessment of omega 3 oil sources for use in aquaculture - alternatives to the unsustainable harvest of wild fish stocks. Doctor Dessertation. University of Tasmania. 226p.

Miles, R.D. and Chapman, F.A., 2006 . The Benefits of Fish Meal in Aquaculture Diets.

http://www.thefishsite.com/articles/200/th e-benefits-of-fish-meal-in-aquaculturediets. Diambil tanggal 8 Oktober 2011, jam 15.10

Murray, J. and Burt, J.R., 2001. The composition of fish. Ministry of Technology. Torry research station, Torry advisory note no. 38 dalam FAO Corporate Document Repository. 
NRC (National Research Council), 1993. Nutrient Requirements of Fish. National Acad. Press, Washington, DC. 114 p.

Olsen, R. S.J, Langmyhr, E, Mundheim, H, Ringoe, E, Melle, W, Malde, M.K. and Hemre, G.I., 2006. The replacement of fish meal with Antarctic krill, Euphausia superba in diets for Atlantic salmon, Salmo salar. Aquaculture Nutrition, 12, $280-290$.

Olsen, R. E., Hansen, A.C., Rosenlund, G., Hemre, G.I., Mayhew, T. M., Knudsen, D. L., Eroldogan, O. T., Myklebust, R. and Karlsen, O., $2007 . \quad$ Total replacement of fishmeal with plant proteins in diets for Atlantic cod (Gadus morhua L.) II - health aspects. Aquaculture, 272, $612-624$.

Orban, E., Nevigato, T., Di Lena, G., Casini, I., and Marzetti, A. 2003. Differentiation in the lipid quality of wild and farmed seabass (Dicentrarchus labrax) and gilthead sea bream (Sparus aurata). J. Food Sci. 68(1): 128-132.

Park, H.G., Puvanendran, V., Kellett, A., Parrish, C.C. and Brown J.A., 2006. Effect of enriched rotifers on growth, survival, and composition of larval Atlantic cod (Gadus morhua). Mar. Sci., 63, 2, $285-295$.

Pauly, D., Christensen, V., Guenette, S., Pitcher, T., Sumaila, U.R., Walters, C., Watson, R. and Zeller, D., 2002. Towards sustainability in world fisheries. Nature, 418, 689 - 695.

Penha-Lopez, G., Rhyne, A., Lin, J. and Narciso, L., 2005. The larva rearing of the marine ornamental crab. Aquacult. Res., 36, 1313 - 1321.

Place, A.R. and Harel, M., 2006. Use of arachidonic acid for enhanced culturing of fish larvae and broodstock. University of Maryland Biotechnology Institute (Baltimore, MD, US).

Roo, F., Socorro, J., Izquierdo, M.S., Caballero, M.J., Hernandez-Cruz, C.M., Fernandez, A. and Fernandez-Palacios, H., 1999. Development of red porgy Pagrus pagrus visual system in relation with changes in the digestive tract and larval feeding habits. Aquaculture, 179, $499-512$.

Rosa, R., Calado, R., Narsico, L. and Nunes, M.L., 2007. Embryogenesis of decapod crustaceans with different life history traits, feeding ecologies and habitats: a fatty acid approach. Mar. Biol., 151, 935 - 947.

Rose, G.A., 2001. Can Newfoundland cod stocks recover without capelin? ICES CIEM Newsletter, 38, 8.

Rustan, A.C and Drevon, C.A., 2005. Fatty Acids: Structures and Properties. http://www.uio.no/studier/emner/matnat/f armasi/FRM2041/v06/undervisningsmate riale/fatty_acids.pdfhttp://www.uio.no/stu dier/emner/matnat/farmasi/FRM2041/v06 /undervisningsmateriale/fatty_acids.pdf. Diambil tanggal 8 Oktober, jam 14.05.

Sargent J.R., Bell J.G., McEvoy L.A., Tocher D. and Estevez A., 1999. Recent developments in the essential fatty acid nutrition of fish. Aquaculture, 177, 191199.

Sargent, J.R., Tocher, D.R., Bell, J.G., 2002. The lipids, In: Halver, J.E., Hardy, R.W. (Eds.), Fish Nutrition, 3rd edition. Academic Press, San Diego, 181-257.

Sawanboonchun, J., 2009. Atlantic Cod (Gadus morhua L.) Broodstock Nutrition: The Role of Arachidonic Acid And Astaxanthin As Determinants Of Egg Quality. Institute of Aquaculture, University of Stirling, Scotland. Doctoral Thesis, $212 \mathrm{p}$.

Seiffert, M.E.B., Cerqueira, V.R. and Madureira, L.A.S., 2001. Effect of dietary $(n-3)$ highly unsaturated fatty acids on growth and survival of fat snook (Centropomus parallelus, Pisces: Centropomidae) larvae during first feeding. Brazilian Journal of Medical and Biological Research, 34, 645 - 651.

Sheridan, M.A., 1988. Lipid dynamics in fish : Aspects of absorption, transportation, deposition and mobilization. Comp. Biochem. Physiol., 90, $679-690$.

Stottrup, J.G., 2000. The elusive copepods: their production and suitability in marine 
aquaculture. Aquaculture Research, 31, $703-711$.

Szkudelski, T., Szkudelski, K., and Nogowski, L., 2009. Effects of adenosine as receptor antagonism on lipogenesis and lipolysis in isolated rat adpocytes. Physiol. Res., 58, $863-871$.

Tacon, A.G.J. and Metian, M., 2008. Global overview on the use of fish meal and fish oil in industrially compounded aquafeeds: Trends and future prospects. Aquaculture, 285, 146 - 158.

Thorsen, A., Trippel, E. A., and Lambert, Y., 2003. Experimental methods to monitor the production and quality of eggs of captive marine fish, Northwest Atl. Fish Sci, 33, 55 - 70.

Tocher, D.R., 2003. Metabolism and functions of lipids and fatty acids in teleost fish. Rev. Fish Sci., 11, 107 184.

Tocher, D.R., Eldar, A. Bendiksen, B, Patrick, J. Campbell, B., Gordon B.J.,
2008. The role of phospholipids in nutrition and metabolism of teleost fish. Aquaculture, 280, 21-34

Veloza, A.J., Chu, F.L.E. and Tang, K.W., 2006. Trophic modification of essential fatty acids by heterotrophic protists and its effects on the fatty acid composition of the copepod Acartia tonsa. Marine Biology, 148, 779 - 788.

Watanabe, T., and Vassallo-Agius, R., 2003. Broodstock nutrition research on marine finfish in Japan. Aquaculture, $227,35-61$.

Watanabe, T., 2007. Importance of Docosahexaenoic Acid in Marine Larval Fish. Journal of the World Aquaculture Society, 24, 2, $152-161$.

Yildiz, M., 2008. Fatty Acid Composition of Some Commercial Marine Fish Feeds Available in Turkey. Turk. J. Vet. Anim. Sci, 32, 3, $151-158$. 